\title{
Multicultural and Multiethnic \\ Tolerance Determined \\ by School Culture and Behavior
}

\begin{abstract}
In times of intensive changes in all areas of our social environment that are meant to lead toward globalization, there are still reports by relevant institutions and media that show an increased tendency of cultural and ethnic separation among the young generation. As this fact gives rise to concern, we believe that educational system must be addressed for help in order to overcome these problems successfully. It is our opinion that the current situation requires an appropriate treatment of the existing abilities and capacities of our educational system so that it can strengthen multiculturalism, contribute toward better multiethnic relations, promote and provide respect, tolerance and mutual acceptance.
\end{abstract}

For this reason, the paper focuses on school organization and functioning as the main pillar of this system, with a special emphasis on creating the school culture and behavior as an irreplaceable tool for creating an environment filled with tolerance and cohabitation among the youth.

Keywords: school culture, multicultural, multiethnic, cohabitation, tolerance.

\section{Introduction}

We have to be sensible and admit that regardless of the fact that we have entered the $21^{\text {st }}$ century - the greatest challenges that we are still facing include the creation of a democratic society as a prerequisite for providing the basic postulates for equal development of all resources, particularly the human ones. The question now arises as to why the Western Balkan countries, which resolved most of this kind of issues quite successfully within the former federation, have to tackle the same issues of mutual tolerance and cohabitation all over again. Our firm stance is that one of the most serious reasons for this state of affairs lies in the faults of the educational system, or rather, the negligence of the role of education in teaching the young generations to live together and tolerate one another. It is a fact that over the past years these countries have supported more or less ethnic segregation in schools in order to avoid conflicts among the younger generations of different nationalities. Instead of contributing to a better integration of diverse young generations,

1 d.petrovski@pfbt.uklo.edu.mk Copyright $\odot 2017$ by the authors, licensee Teacher Education Faculty University of Belgrade, SERBIA.

This is an open access article distributed under the terms of the Creative Commons Attribution License (CC BY 4.0) (https://creativecommons.org/licenses/by/4.0/), which permits unrestricted use, distribution, and reproduction in any medium, provided the original paper is accurately cited. 
this tactics of the educational policies has widened the gap between them, which consequently led to stronger ethnic group boundaries. In some of these countries, such as the Republic of Macedonia, students residing in multiethnic areas attend classes either in different forms or in opposite school shifts. One may ask - is this the way to design an integrated educational system as the fundamental precondition for developing social cohesion and democratic principles in multicultural societies?

The significance of tolerance as a principle of action that can help in overcoming such situations is the reason why in this paper we try to remind the readers how tolerance is acquired, realized, and enhanced by means of an improved school culture.

\section{Acquisition of proper knowledge of intercultural and interethnic tolerance}

History shows that until the year 1945 a commonly accepted standard had been that everyone living in a certain state was to assimilate with the prevailing ethnicity. On the other hand, there were certain periods in the history of Central and Eastern European countries with positive experiences of a peaceful cohabitation with mutual tolerance and respect. Multiculturalism emerges as a new concept of social order only after the WW2, mostly in Western Germany and primarily due to the experience with immigrants. This concept advocates political recognition of equality between minority communities formerly considered specific in terms of ethnicity and the majority of the host country. Although this undoubtedly represents a radical departure from the policy of assimilation, the fact is that multiculturalism often shared the same schematic concept of social division into a majority and a minority, differing only in the right given to the minority to separate from the majority, rather than to assimilate with it.

This paradigm was rejected by the Council of Europe with a Declaration on Intercultural
Dialogue and Conflict Prevention adopted in Opatija, Republic of Croatia in 2003. The stand was taken in favour of cultural diversity and an argument put forward that this principle cannot be applied exclusively by defining the 'majority' and 'minority' because such a model separates different culture communities, puts them into a category, and stigmatizes them to the extent that social behavior and cultural stereotypes are assumed on the basis of the status of the respective group. The identities overlapping partially are not contradictory; on the contrary, they are a source of strength and indicate the possibilities of creating a common basis (Council of Europe, 2003).

The intercultural and interethnic tolerance is a matter regulated under the Framework Convention for the Protection of National Minorities. Under this convention, the parties shall encourage a spirit of tolerance and intercultural dialogue "and take effective measures to promote mutual respect and understanding and co-operation among all persons living on their territory, irrespective of those persons' ethnic, cultural, linguistic or religious identity" (Council of Europe, 2010, in: Democratic Governance Group Bureau for Development Policy, 2010), in particular in the fields of education, culture and the media.

\section{Tolerance}

It is probably due to the disrespect of differences that led to various clashes, even wars, that the United Nations General Assembly proclaimed the year 1995 as the United Nations Year for Tolerance.

Given its significance for the realization of democratic processes, tolerance has been cited in many documents and by a large number of authors. As defined by UNESCO, tolerance is "respect, acceptance and appreciation of the rich diversity of our world's cultures, our forms of expression and ways of being human. It is fostered by knowledge, 
openness, communication, and freedom of thought, conscience and belief. Tolerance is harmony in difference. It is not only a moral duty, it is also a political and legal requirement" (UNESCO, 1995: $1)$.

Tolerance is the first stage of a longer-range process leading towards the development of a culture of peace. It is the minimal essential quality of social relations that eschew violence: "Without tolerance, peace is not possible. With tolerance, a panoply of positive human and social possibilities can be pursued, including the evolution of a culture of peace" (UNESCO (1994). Tolerance: the threshold of peace A teaching / learning guide for education for peace, human rights and democracy (UNESCO, 1994: 14).

The maintenance and fostering of intercultural and interethnic tolerance in the countries of the region is one of the basic preconditions for the development of democratic principles and ensuring social cohesion. In a country where there is no tolerance, it is impossible to secure the inclusion of members of ethnic communities in all spheres of social life and to guarantee equal opportunities for them.Therefore, the necessary support is provided by international regulations which regulate a part of this issue. The Western Balkan countries have ratified the major international human and minority rights conventions and are in the process of adopting the Acquis Communauitaire. In 2008, the ministers of education from the countries of the Southeast Europe signed a Joint Statement on the Commitment to the Development of Human Capital in Southeast Europe (Spasovski, Ballazhi \& Friedman, 2010: 10). This statement is "a commitment to promote: quality, diversity and equitable access to education; innovatory capacity within education systems; and intercultural capacities of educational institutions as key prerequisites to the prosperity and sustainable development of the Western Balkan countries and their integration to the EU" (Batarelo Kokić, et al., 2010).

\section{The significance of school culture in overcoming the barriers that impede intercultural and interethnic tolerance}

If there have been any dilemmas about the question of whether and to what extent school culture, or perhaps education as a whole, can contribute to pulling down the barriers that hinder tolerance and coexistence, they will no longer be in the way. Those dilemmas have been removed not only with the provisions set in the Statement mentioned in the previous paragraph, but also with the international documents which confirm that the competences necessary for intercultural dialogue are not automatically acquired: they need to be learned, practiced and maintained throughout life (Council of Europe, 2008: 29). According to these documents, in a multicultural Europe, education is not only a means of preparing for the labor market, supporting personal development and providing a broad knowledge base; schools are also important for the preparation of young people for life as active citizens (Council of Europe, 2008: 30).

Now the question arises as to what stage our schools have reached in providing support for achieving the generally accepted values regarding coexistence and tolerance in a multiethnic, multicultural and multi-confessional environment such as ours. Have they adequately tackled the challenge of finding and institutionalizing appropriate mechanisms for the functioning of different ethnicities, i.e., have they established appropriate coexistence and tolerance among different ethnic communities upon the fact that the earlier the age of the population involved in these processes, the more sustainable tolerance and cohabitation? Unfortunately, everyday practice and the recent research have shown that our schools are not fully up to their task, and despite the welcomed advantages of multiculturalism in education, they have still not provided an improvement in interethnic relations. In other words, our students are burdened with ethnic stereotypes and prejudices, 
mainly positive about their own ethnic group, and negative about the 'others' (UNICEF, 2009).

\section{School culture and behavior ensuring tolerance and coexistence}

We believe that a successful overcoming of those negative situations can only occur if our schools manage to build and cherish appropriate culture and behavior of all participants in the educational process. This is supported by the wellknown fact that people throughout their lives should continually be "exposed" to cultural influence, because culture is something that is acquired.

What should students, teachers, professional services and all others included in this process acquire and learn together in order to build the desired school culture which will provide the appropriate behavior? In that direction, we are convinced that it is not possible to expect any cultural development from students or teachers if they themselves are not familiar with their own culture in the first place. The process of learning one's own culture is called Enculturation (Ширилова, 2001). Apart from parents and the social environment as very important factors, schools should also have a great influence in one's learning about one's own culture. They need to build the mechanisms that will allow pupils at the earliest age to realize that they belong to a particular culture, and this belonging is acquired in the process of socialization, but that they also have full freedom of choice as to which culture they will belong to when they grow up. However, this is not enough. In the conditions of multicultural, multinational and multi-confessional surroundings, the knowledge of only one's own culture cannot ensure coexistence and tolerance, i.e., positive interaction among different cultural groups. In order for a school to create the appropriate culture and behavior that will have positive implications on the coexistence and tolerance, not only in the schoollife, but wider as well, mutual knowledge, acceptance, and recognition of diversity in all aspects of life (cultural, ethnic, religious, etc.) are highly necessary among the members of a community. Only by knowing each other well, they will be able to respect each other because only in this way will they be able to provide joint projections of appropriate social progress and development. This means that acculturation is a necessity.

Acculturation is a process of establishing contacts between two cultures, namely, a process in which different groups or individuals who interact with one another, change their cultural characteristics and acquire new ones (Prangoska, 1999).

Acculturation is a kind of cultural change that represents a process of dialectical interaction between the cultures of two or more social groups that for any reasons come into contact; i.e., a process in which they encounter, contact and interact with two cultures.

Acculturation is also defined as:

1. Modernization of primitive culture

2. Taking and adopting elements of foreign cultures

3. Acceptance of the culture of the new environment to which an individual or a group has come (Širilova,2001).

Once the aforementioned assumptions have been provided, it will surely be easier for schools to continually create, upgrade and maintain the school culture and behavior -both in the long run and at all three levels.

The first level of school culture includes external manifestations of culture. Therefore, this level does not reflect the entire school culture, but only its most visible, obvious, and accessible aspects that people can discern. Such visible manifestations of school culture include forms of behavior that can be seen and heard, and accordingly "send a message" to all participants in the educational process (parents, students, teachers, etc.). However, in order to send 
a message to all, the very important task of each school is to ensure that the applied elements of the first level of school culture are generally acceptable or that they reflect the cultural diversity and thus provide the basis for removing any barriers to all participants'equality in the educational process.

The most visible elements of school culture are usually artefacts (furniture, equipment, work clothes); language (the way of mutual communication); norms (expected forms of behavior based on the values of a school and beliefs that those values provide guidance on the behavior for all); rituals (recurrent sequence of activities that expresses and strengthens the main values and beliefs), slogans (short phrases regularly interchanged to advertise or to motivate employees; stories (usually based on true events, but may include a mixture of true and fictional work) logo/symbols (distinguishing marks).

The second level refers to school values and beliefs. Values and beliefs are basic elements the purpose of which is telling people what they should strive for and how they should behave. It is very difficult for these terms to be separated, so they are often considered identical terms. Values and beliefs are found under the surface events as supporting armature. Although these values are not visible, they can make individuals aware of their existence. These values and beliefs are the elements that distinguish one school from another, that is, according to several analysts, the actual elements that make the school culture genuine. Being part of the school culture, the question is what these values are in fact. Generally, they are expansive tendencies based on moral, social or religious principles learned in childhood and changed through experience, or organizational solutions to problems experienced over the past. Accordingly, it becomes clear that - through the mechanisms of school culture,schools have a chance to succeed in developing the virtues and beliefs in the young generations about mutual respect, coexistence and tolerance as the key solution to the problems that have been present in the Republic of
Macedonia for a long time, not to mention their troublesome consequences.

The basic presuppositions are included in the third level and represent the deepest component of school culture. These are systematized basic human knowledge and experiences about how the world around works and what is the nature of the things that surround them. These are the assumptions that individuals have about the school and its success in building a system of coexistence and tolerance: whether such a system functions, what attitude the school has to its surroundings, etc. They are invisible, subconscious, and "taken for granted" and therefore quite difficult to discern. The subconscious character of the underlying assumptions decreases, but does not, however, exclude the possibility for schools to influence this part of the school culture.

\section{Conclusion}

From what we have stated, it becomes clear that school culture would not be such a significant issue if there were no indications of its significant impact on the successful functioning, not only of the school, but more widely as well. It is this conclusion that emphasizes the new role that schools should have in overcoming negative practices, primarily in providing assistance to the youngest generations in achieving a balance of diversity, respecting the freedoms and rights of different groups and securing appropriate coexistence and tolerance. Only a school culture that promotes common values and respect of human rights, democracy, and law can lead to unity, tolerance, and coexistence. In this regard, our schools must accept the good European practices and fully utilize the identifiers of the key knowledge about intercultural communication when creating and implementing the curricula and the teacher training programs. We must create a school culture in which pupils and students will be motivated to acquire signifi- 
cant critical thinking skills necessary for their own attitudes and responses to the experiences not only of their own, but also of other cultures.

\section{Literature}

- Batarelo Kokić, I., Vukelić, A., Ljubić, M. (2010). Mapping Policies and Practices for The Preparation of Teachers for Inclusive Education in Contexts of Social and Cultural Diversity, Croatia Country Report. Turin, IT: European Training Foundation.

- Council of Europe (1995). Framework convention for the protection of national minorities and explanatory report. Strasbourg, FR: Retrieved March 23, 2017, from https://www.coe.int/t/dghl/monitoring/minorities/1_ atglance/PDF_H\%2895\%2910_FCNM_ExplanReport_en.pdf

- Council of Europe, (2003). Declaration on Intercultural dialogue and conflict prevention. Strasbourg, FR: Retrieved June 15, 2017, from http://www.coe.int/T/E/Com/Files/Ministerial-Conferences/2003-Culture/declaration.asp

- Council of Europe (2008). White Paper on Intercultural Dialogue "Living Together as Equals in Dignity". Strasbourg, FR: Council of Europe.

- Democratic Governance Group Bureau for Development Policy (2010). Marginalized Minorities in Development Programming, A UNDP Resource Guide and Toolkit. New York, NY: Retrieved March 03, 2017, from: http://hrbaportal.org/wp-content/files/UNDPMarginalisedMinorities.pdf

- Prangoska, L. (1999). Osnovi na psihologijata [The Fundaments of Psychology]. Ohrid, MK: IIT \& Faculty of Tourism and Hospitality.

- Spasovski, O., Ballazhi, S., \& Friedman, E. (2010). Mapping policies and practices for the preparation of teachers for inclusive education in contexts of social and cultural diversity, Country Report for the former Yugoslav Republic of Macedonia. Torino, IT: Retrieved March 03, 2017. from http://www.pedocs.de/volltexte/2014/8497/pdf/Spasovski_etal_2010_Mapping_Policies.pdf

- Ширилова, В. (2001). Голем лексикон на сйрански зборови и изрази. Скопје, МК: Топер.

- UNESCO (1994). Tolerance: the threshold of peace A teaching / learning guide for education for peace, human rights and democracy. Paris, FR: UNESCO.

- UNESCO, (1995). Declaration of principles on tolerance. Paris, FR: Retrieved May 03, 2017, from: http:// www.unesco.org/webworld/peace_library/UNESCO/HRIGHTS/124-129.HTM

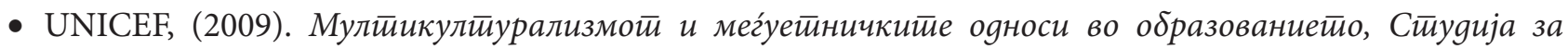

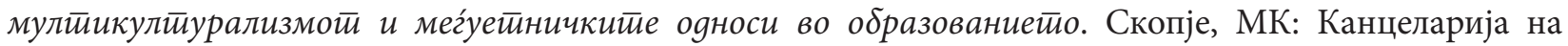
УНИЦЕФ. 


\section{Добри Ј. Петровски}

Кристина Д. Петровска

Учитељски факултет, Универзитет „Св. Климент Охридски“ у Битољу,

БЈР Македонија

\section{Мултикултурна и мултиетничка толеранција одређена школском културом и понашањем}

Резиме: Иниензивне ирромене gо којих је gошло у образовағу и gруіим областиима

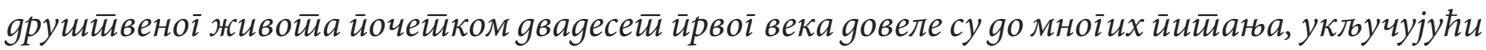
и ово: зашйо су ове ирромене, уместио gа унайреgе иниееірације и ілобализацију, нажалости gовеле gо још израженијих йоgела међу млаgима на кулйурној и етиничкој основи?

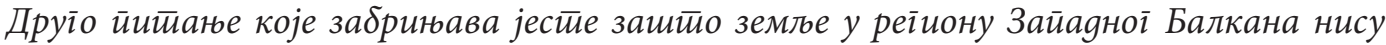

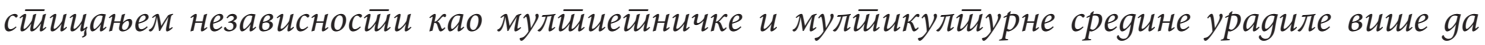
унайреgе инйеірације и йревазиђу верске, еитнчке и кулитурне разлике. Зашйо земле у реіиону, које су gобро функиионисале у зајеgничкој феgерацији, у којој су йроблеми ове врсте уілавном били иревазиђени, морају йоново gа се баве йитианима йойуй узајамне йолераниије и суживотиа?

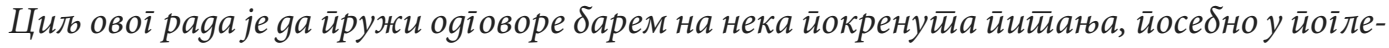

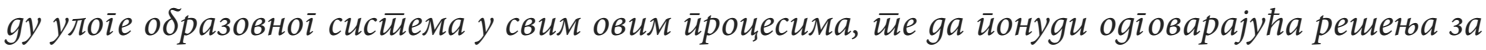

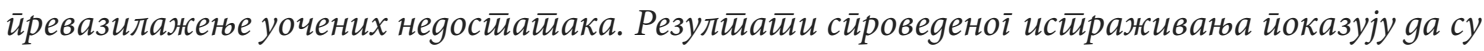

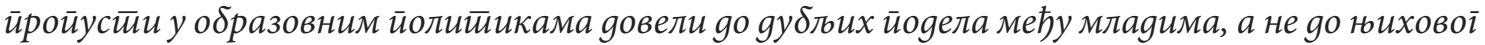
већеі̄ иниетеірисаюа. Унеким gржавама Зайаgноі Балкана, као шйо је Рейублика Макеgонија,

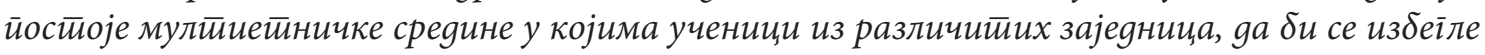

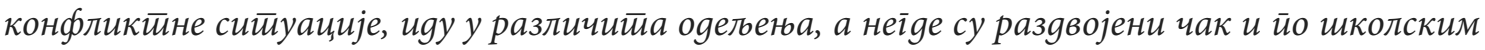
сменама.

То су разлози зашито се у овом раgу фокусирамо на оgі̄оварајућу оріпанзацију и фбнкицонисане школе као основноі йреgуслова за усиешну реализацију юене улоїе у сииварану

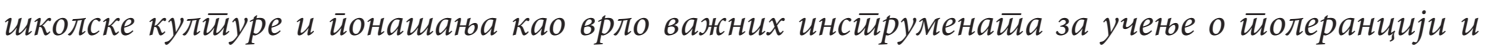
заједничком животиу.

Ови найори ӣреgстиављају изазов у смислу коришћена свих расйоложивих научних саз-

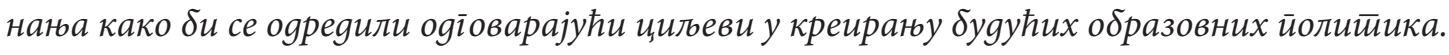

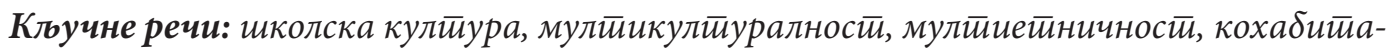
иија, йолераниија. 